\title{
PENGARUH KONSENTRASI PERENDAMAN ASAM KLORIDA PADA LIMBAH TULANG KAKI KAMBING TERHADAP KEKUATAN GEL, VISKOSITAS, WARNA DAN KEJERNIHAN, KADAR ABU DAN KADAR PROTEIN GELATIN
}

\author{
EFFECT OF CONCENTRATION OF HYDROCHLORIC ACID SOAKING ON GOAT LEG \\ BONE AFFAL TOWARDS GEL STRENGTH, VISCOSITY, COLOR AND CLEARNESS, ASH \\ AND PROTEIN CONTENT OF GELATINE
}

\author{
Juliasti, $\mathbf{R}^{1}$., A. M. Legowo ${ }^{2}$, Y. B. Pramono ${ }^{3}$ \\ Fakultas Peternakan dan Pertanian Universitas Diponegoro \\ Email: radiajuliasti@gmail.com
}

\begin{abstract}
This study was conducted to investigate the characteristics of leg bone of goat with immersion of hydrochloric acid (HCl) to get physical and chemical quality according to standartd GMIA (2012) and ISO (1995). The materials used were "tarsometatarsus" part of goat leg bone, $\mathrm{HCl}, \mathrm{NaOH}$, baking soda and distilled water. The experiment used Completely Randomized Design (CRD) with 4 treatments and 5 replications, with $\mathrm{HCl}$ concentration of $1,5 \%, 3 \%, 4,5 \%$ and $6 \%$. The bones were soaked for 24 hours. The data obtained was analyzed with analysis of variance (ANOVA) at significance level of 5\%, continued by Duncan Multiple Range Test (DMRT) if there was significant effect. The parameters observed include color quality and charity, gel strength, viscosity, ash content and protein component. The results showed that various $\mathrm{HCl}$ acid immersion treatments significantly affected $(P<0.05)$ gel strength, viscosity, ash content and protein component but not significantly affected $(P>0.05)$ color and charity. Immersion with $\mathrm{HCl}$ at 3-4,5\% concentration for 24 hours obtained gelatin with physical and chemical quality according to GMIA (2012) and ISO (1995) standard.
\end{abstract}

Key words: gelatin, bone goat, chloride acid (HCl), physical and chemical quality.

\section{ABSTRAK}

Penelitian ini bertujuan untuk mengetahui karakteristik gelatin tulang kaki kambing dengan perlakuan perendaman konsentrasi asam klorida $(\mathrm{HCl})$ yang tepat untuk mendapatkan kualitas fisik dan kimia gelatin yang sesuai standar GMIA (2012) dan SNI (1995). Materi yang digunakan adalah tulang kaki kambing bagian "tarsometatarsus", $\mathrm{HCl}, \mathrm{NaOH}$, soda kue dan aquades. Rancangan percobaan yang digunakan Rancangan Acak Lengkap (RAL) dengan 4 perlakuan dan 5 ulangan dengan konsentrasi $\mathrm{HCl}$ 1,5\%, 3\%, 4,5\% dan 6\% perendaman selama $24 \mathrm{jam}$. Data yang diperoleh akan dianalisis menggunakan analisis of variance (ANOVA) dengan taraf signifikansi 5\%. Apabila ada pengaruh perlakuan maka dilanjutkan dengan menggunakan Uji Wilayah Ganda Duncan. Parameter yang di amati meliputi kualitas warna dan kerjernihan, kekuatan gel, viskositas, kadar abu dan kadar protein. Hasil penelitian menunjukkan bahwa adanya pengaruh nyata $(\mathrm{P}<0,05)$ antara perendaman berbagai konsentrasi $\mathrm{HCl}$ pada kekuatan gel, viskositas, kadar abu, kadar protein, dan tidak berpengaruh nyata $(\mathrm{P}>0.05)$ terhadap warna dan kejernihan. Perlakuan perendaman konsentrasi $\mathrm{HCl} 3-4,5 \%$ selama 24 jam menghasilkan kualitas fisik dan kimia gelatin yang sesuai standar GMIA (2012) dan SNI (1995).

Kata kunci : gelatin, tulang kambing, asam klorida $(\mathrm{HCl})$, kualitas fisik dan kimia.

\section{PENDAHULAN}

Gelatin adalah sumber protein tinggi yang berasal dari proses hidrolisis kolagen kulit maupun tulang rawan. Gelatin dapat dimanfaatkan sebagai produk permen dan coklat pada industri pangan, sedangakan pada industri non pangan, gelatin digunakan dalam pembuatan cangkang kapsul, industri fotografi. Gelatin juga dapat digunakan sebagai bahan pelapis (coating) untuk mengawetkan bahan makanan.

Gelatin merupakan hasil hidrolisis parsial kolagen yang diperoleh melalui ekstraksi dalam air panas yang dikombinasikan dengan perlakuan alkali atau asam (Poppe, 1992). Pemanfaatan tulang kaki kambing sebagai sumber gelatin untuk saat ini masih sangat minim dilakukan. Sumber gelatin yang umum digunakan berasal dari tulang sapi maupun tulang babi, dimana sumber gelatin dari terbesar berasal di dunia berasal dari kulit babi sapi menjadi masalah bagi umat islam dan hindu. oleh karena itu limbah dari kaki kambing adalah salah satu alternatif sumber bahan baku untuk membuat gelatin yang halal. Saat ini Indonesia masih melakukan impor gelatin yang berasal dari Negara-negara Eropa dan Amerika sebesar 2000-3000 ton pertahun (Saleh et al., 2002).

Ekstrasi gelatin terbaik dan efisien membutuhkan metode dan penggunaan 
peremdaman yang tepat agar menghasilkan karakteristik fisik dan kimia gelatin yang sesuai standar. Gelatin dibedakan menjadi dua tipe berdasarkan proses pembuatannya yaitu tipe A yang dihasilkan melalui proses asam dan tipe $\mathrm{B}$ yang diprodksi melalui proses basa (Imeson, 1992). Proses pembuatan gelatin tulang kaki kambing menggunakan proses asam, karena perendaman menggunakan asam relative cepat yang hanya 3-4 minggu dibandingkan dengan proses basa sekitar 3 bulan (Said, 2011). Asam yang digunakan untuk pembuatan gelatin tulang kaki kambing yaitu asam klorida $(\mathrm{HCl})$ yang bertujuan untuk mempercepat ossein dari pada menggunakan proses basa.

Tujuan penelitian ini adalah untuk mengetahui karakteristik gelatin tulang kaki kambing dengan perlakuan perendaman konsentrasi asam klorida $(\mathrm{HCl})$ yang tepat untuk mendapatkan kualitas warna dan kejernihan, kekuatan gel,viskositas,kadar abu dan kadar protein sesuai dengan standar gelatin.

\section{METODE PENELITIAN}

\section{Bahan dan Alat}

Bahan yang digunakan untuk penelitian ini adalah tulang kaki kambing jawarandu bagian tarsometatarsus berumur 612 bulan yang di ambil dari Rumah Potong Hewan Kampung Bustaman Kota semarang, $\mathrm{HCl}, \mathrm{NaOH}$, soda cair dan aquades. Peralatan yang digunakan dalam pembuatan gelatin adalah timbangan analitik, HPLC, saringan, waterbatch, spectrofotometer, gelas ukur, beaker glass, oven, cawan petri, cawan porselin, tanur, labu kjeldahl, desikator, erlemeyer, chiller, $\mathrm{pH}$ meter, $\mathrm{pH}$ stik, pipa ostwald.

\section{Tahapan Penelitian}

Tulang kambing dipotong kecil-kecil dan dibersihkan dari lemak serta daging yang masih menempel sampai bersih, tulang ditimbang dan dibagi-bagi untuk dimasukkan kedalam toples kaca sesuai berat yang diinginkan dan direndam menggunakan aquades dengan pembanding dua kali lipat dari berat tulang. Selanjutnya dilakukan perebusan (degreasing) dalam waterbath selama 4 jam dengan suhu $70^{\circ} \mathrm{C}$. Sementara itu dilakukan pengenceran $\mathrm{HCl} 1,5 \%, 3 \%$, $4,5 \%$ dan $6 \%$ mengunakan aquades, penentuan konsentrasi perendaman HCL berdasarkan (Hajrawati, 2006). Tulang yang selesai direbus langsung dilakukan demineralisasi $\mathrm{HCl} 5 \%$ selama \pm 5 hari dan dilakukan pergantian air $\mathrm{HCl}$ setiap 24 jam yang bertujuan agar konsentrasi $\mathrm{HCl}$ nya tidak berubah. Setelah proses demineralisasi dilakukan pencucian menggunakan air mengalir sampai $\mathrm{pH}$ normal dan perendaman menggunakan soda cair selama 15 menit agar mineral tulang yang tersisa terbuang sempurna. Selanjutnya ossein yang didapat dari proses demineralisasi direndam dalam larutan $\mathrm{HCl}$ dengan konsentrasi yang berbeda yaitu $1,5 \%, 3 \%, 4,5 \%$ dan $6 \%$ selama 24 jam. Hasil dari ossein dilakukan pencucian dan dilanjutkan dengan menggunakan $\mathrm{NaOH} 0,1$ $\mathrm{N}$ lalu dilakukan pencucian yang terakhir menggunakan air yang mengalir sampai $\mathrm{pH}$ netral (6-7), ossein yang selesai dicuci sampai $\mathrm{pH}$ normal dilanjutkan dengan ekstraksi dalam waterbath dengan suhu $65^{\circ} \mathrm{C}$ (4 jam), $75^{\circ} \mathrm{C}\left(4\right.$ jam),dan $85^{\circ} \mathrm{C}$ (5 jam) dan ekstrak disaring menggunakan kain mori, hasil ekstraksi dijadikan satu dan di panaskan kembali dalam waterbath selama 3 jam agar air yang masih terkandung dapat menguap dan memepermudah proses pengeringan, gelatin di cetak dan dikeringkan dalam kardus yang diberi dua lampu 5 watt. Parameter pada penelitian ini meliputi warna dan kejernihan, kekuatan gel,viskositas,kadar abu dan kadar protein. Data yang diperoleh akan dianalisis menggunakan analisis of variance (ANOVA) dengan taraf signifikansi 5\%. Apabila ada pengaruh perlakuan maka dilanjutkan dengan menggunakan Uji Wilayah Ganda Duncan.

Kekuatan Gel (British Standard 757, 1975)

Sampel sebanyak $6,67 \%$ dilarutkan dalam aquades sampai mencapai volume 100 $\mathrm{ml}$ dalam labu takar, kemudian dipindahkan dalam gelas piala $100 \mathrm{ml}$ dipanaskan sebentar sampai gelatin larut kemudian didinginkan pada suhu $10^{\circ} \mathrm{C}$ selama 17 jam. Gel yang terbentuk selanjutnya dianalisis menggunakan Volland-Stevens LFRA Texture Analizer dengan satuan bloom 
(menentukan berat dalam gram dengan diameter 0,5 inci).

Viskositas Gelatin (British Standard 757 1975)

Viskositas gelatin diukur dengan cara larutan gelatin dengan konsentrasi 6,67\% (b/b) disiapkan dengan aquades kemudian diukur viskositasnya dengan menggunakan vicnometer Ostwald 350. Penetapannya dilakukan dengan mengukur waktu yang diperlukan gelatin untuk mengalir dalam pipa baris batas atas hingga batas bawah .larutan gelatin pada suhu $40^{\circ} \mathrm{C}$ dan $60^{\circ} \mathrm{C}$, larutan dimasukkan kedalam vicnometer Ostwald, kemudian dihisap hingga diatas batas atas pipa kapier dan kemudian dibiarkan mengalir hingga batas bawah yang diakukan pencatatan waktu menggunakan stopwatch. Kemudian dilakukan berat jenis gelatin (densitas) dengan menggunakan vicnometer $10 \mathrm{ml}$, sehingga diperoleh berat jenisnya rumus 1.Setelah mendapatkan densitas dan waktu alir gelatin, kemudian dihitung viskositas gelatin menggunakan Rumus 2 .

Rumus $1: \rho \mathrm{x}=\frac{y}{v}$

Keterangan :

$\rho \mathrm{x}=$ densitas gelatin

$\mathrm{y}=$ berat gelatin $(\mathrm{g})$

$\mathrm{v}=$ volume gelatin $(\mathrm{ml})$

$\mathrm{tx}=$ waktu alir gelatin

Rumus $2: \mu \mathrm{x}=\frac{t x X \rho x}{t s X \rho s} X \mu s$

ts $=$ waktu alir aquades

$\rho \mathrm{x}=$ densitas gelatin

$\rho s=$ densitas aquades

$\mu \mathrm{s}=$ viskositas aquades $(1 \mathrm{cp})$

Warna dan tingkat kejernihan gelatin (Schrieber dan Garies, 2007)

Larutan gelatin dibuat dengan konsentrasi $6.67 \%(\mathrm{~b} / \mathrm{b})$ disiapkan dengan aquades. Warna gelatin diukur dengan menggunakan spektrofotometer dengan panjang gelombang $450 \mathrm{~nm}$, sedangkan clarity diukur dengan menggunakan panjang gelombang 620 nm.Aquades digunakan sebagai larutan standar.

\section{Kadar Protein (AOAC, 1995)}

Sampel seberat 0.2-0.05 g dimasukkan dalam labu Kjeldahl $100 \mathrm{ml}$, kemudian ditambahkan 2-3 g katalis (1.2 g $\mathrm{Na}_{2} \mathrm{SO}_{4}$ dan 1 g $\mathrm{CuSO}_{4}$ dan $2 \mathrm{ml} \mathrm{H}_{2} \mathrm{SO}_{4}$ pekat. Dilakukan destruksi sampai larutan menjadi jernih. Setelah itu didinginkan kemudian sampel didestilasi dan ditambahkan $35 \mathrm{ml}$ aquades dan $10 \mathrm{ml} \mathrm{NaOH} \mathrm{50 \% .} \mathrm{Hasil}$ destilasi dalam erlenmeyer $125 \mathrm{ml}$ yang berisi $5 \mathrm{ml} \mathrm{H} \mathrm{BO}_{3}$ kemudian dititrasi dengan $\mathrm{HCl}$ $0.02 \mathrm{~N}$ dengan menggunakan indikator. Hal yang sama dilakukan untuk blanko. Persentase nitrogen dan kadar protein kasar dihitung dengan rumus sebagai berikut:

Kadar nitrogen $=$

$\frac{(\mathrm{ml} \mathrm{HCl}-\mathrm{ml} \text { blanko) } \times \text { Normalitas } \mathrm{HCl} \times 14.007}{\text { berat contoh kering }(\mathrm{mg})} \times 100 \%$

Kadar protein $=\% \mathrm{~N}$ x 6.25

Kadar Abu (AOAC, 1995)

Sampel yang telah diuapkan airnya dimasukkan ke dalam tanur bersuhu $600^{\circ} \mathrm{C}$. Sebelumnya berat cawan kering dan berat sampel telah diketahui. Proses penguapan dilakukan sampai semua bahan berubah warna menjadi abu-abu kemudian contoh ditimbang. Kadar abu dihitung dengan menggunakan rumus :

Kadar abu $(\%)=$

$$
\frac{\text { Berat abu }}{\text { Berat Sampel }} \times 100 \%
$$

\section{HASIL DAN PEMBAHASAN}

\section{Kekuatan Gel (Gel Strength)}

Hasil analysis of variance (ANOVA) menunjukkan pengaruh perlakuan perendaman $\mathrm{HCl}$ dengan konsentrasi 1,5-6\% berpengaruh nyata terhadap gelatin tulang kambing disajikan pada Tabel 1.

Perlakuan perendaman $\mathrm{HCl}$ dengan konsentrasi 1,5-6\% menghasilkan nilai gel strength yang berbeda-beda dari setiap perlakuan, hasil gel strength gelatin tulang kambing pada perlakuan $\mathrm{HCl} 6 \%$ dengan nilai 30,76 bloom masih dibawah standar GMIA (2012) yaitu 50-300 bloom. Nilai gel strength gelatin tulang kambing yang memenui standar GMIA (2012) adalah pada 
Tabel 1. Pengaruh Perendaman $\mathrm{HCl}$ dengan Konsentrasi yang Berbeda Terhadap Kekuatan Gel Gelatin Tulang Kaki Kambing

\begin{tabular}{cc} 
Konsentrasi $\mathrm{HCl}(\%)$ & Kekuatan Gel \\
\hline 1,5 & $76,34^{\mathrm{ab}}$ \\
3 & $54,07^{\mathrm{ab}}$ \\
4,5 & $87,54^{\mathrm{a}}$ \\
6 & $30,76^{\mathrm{b}}$ \\
\hline
\end{tabular}

Superskrip yang berbeda menunjukkan perbedaan yang nyata $(\mathrm{p}<0,05)$

perlakuan 1,5-4,5\% yaitu dengan kisaran 54,07-87,54 bloom. Berdasarkan nilai bloom, gel strength gelatin tulang kaki kambing sangat rendah dari gelatin komersial yang memiliki nilai 200-300 bloom (Schrieber dan Garies, 2007).

Berdasarkan Tabel 1. perlakuan perendaman $\mathrm{HCl} 4,5 \%$ selama 24 jam memiliki kekuatan gel yang tertinggi. Kekuatan gel yang tinggi menandakan bahwa gelatin tulang kaki kambing memiliki asam amino yang panjang serta menghasilkan berat molekul yang berbeda sehingga menyebabkan tingginya kekuatan gel yang dihasilkan. Tinggi rendahnya kekuatan gel diduga dipengaruhi oleh viskositas dan $\mathrm{pH}$, tingginya viskositas yang disertai dengan gel strength yang besar menunjukkan bahwa panjangnya rantai asam amino mengandung asam amino prolin dan hidroklisin yang banyak. Semakin tinggi kandungan hidroksiprolin maka semakin tinggi kekuatan gel gelatin yang dihasilkan (Sarabia et al., 2000).

\section{Viskositas}

Tabel 2. Pengaruh perendaman $\mathrm{HCl}$ dengan Konsentrasi yang Berbeda Terhadap Viskositas Gelatin Tulang Kaki Kambing

\begin{tabular}{cll}
\hline \multirow{2}{*}{$\begin{array}{cll}\text { Konsentrasi } \\
\text { HCl }(\%)\end{array}$} & \multicolumn{2}{c}{ Siskositas } \\
\cline { 2 - 3 } & $40^{\circ}$ & $\begin{array}{l}\text { Suhu } \\
60^{\circ}\end{array}$ \\
\hline 1,5 & $3,49^{\mathrm{a}}$ & 1,68 \\
3 & $2,54^{\mathrm{b}}$ & 1,73 \\
4,5 & $2,39^{\mathrm{b}}$ & 2,05 \\
6 & $2,33^{\mathrm{b}}$ & 1,89 \\
\hline
\end{tabular}

Superskrip yang berbeda menunjukkan perbedaan yang nyata $(\mathrm{p}<0,05)$

Nilai viskositas gelatin tulang kaki kambing yang direndam menggunakan $\mathrm{HCl}$ dengan konsentrai 1,5-6\% selama 24 jam disajikan pada Tabel 2.

Perendaman tulang kambing dengan menggunakan HCL 1,5-6\% selama 24 jam memiliki viskositas $\left(40\right.$ dan $\left.60^{\circ} \mathrm{C}\right)$ berkisar antara 1,68-3,49 cP. Nilai viskositas gelatin yang tertinggi dihasilkan dari perendaman dengan $\mathrm{HCl} 1,5$ dan 4,5\% (2,05-3,49 cp) dan viskositas gelatin tulang kambing terendah pada konsentrasi $\mathrm{HCl} 1,5$ dan $6 \%$ (1,68-2,33 cP). Nilai viskositas dilakukan dengan suhu yang berbeda untuk mengetahui peran suhu terhadap viskositas gelatin.

Nilai viskositas gelatin dari tulang kaki kambing yang dihasilkan menurun seiring dengan penambahan konsentrasi $\mathrm{HCl}$ yang diberikan, diduga penurunan nilai viskositas gelatin yang dihasilkan dikarenakan penurunan $\mathrm{pH}$ pada penambahan konsentrasi $\mathrm{HCl}$ yang menyebabkan rantai asam amino menjadi lebih pendek sehingga viskositas dari gelatin menjadi lebih rendah. Pernyataan ini sesuai dengan Astawan et al., (2002) yang menyatakan bahwa tinggi atau rendahnya viskositas gelatin dapat dipengaruhi oleh interaksi hidronamik antar molekul gelatin, $\mathrm{pH}$ dan konsentrasinya.

Semakin tinggi konsentrasi $\mathrm{HCl}$ yang diberikan pada proses asam memberikan pengaruh terhadap perubahan struktur kolagen yang menjadi menyebar yang menyebabkan nilai viskositas yang dihasilkan mengalami perubahan, denga konsentrasi $\mathrm{HCl}$ yang tinggi juga dapat menyebabkan rantai asam amino dan strukturnya terbuka dan rantai tersebut semakin pendek sehingga terjadi penurunan viskositas. Berubahnya struktur rantai kolagen menyebabkan penurunan berat molekul gelatin, hal ini sesuai dengan pernyataan Stainsbay (1977) yang menyatakan bahwa viskositas berhubungan dengan berat molekul rata-rata gelatin. Konsentrasi asam dan lama perendaman yang berbeda dapat berpengaruh terhadap berat molekul yang dihasilkan (Astawan dan Aviana, 2003).

\section{Warna dan Kejernihan}

Nilai warna dan kejernihan gelatin tulang kaki kambing yang direndam menggunakan $\mathrm{HCl}$ 1,5-6\% selama 24 jam 
Tabel 3. Pengaruh Perendaman $\mathrm{HCl}$ dengan Konsentrasi yang Berbeda Terhadap Warna dan Kejernihan Gelatin Tulang Kaki Kambing

\begin{tabular}{ccc}
\hline $\begin{array}{c}\text { Konsentrasi } \\
\mathrm{HCl}(\%)\end{array}$ & Nilai Warna & Kejernihan \\
\hline$----------($ absorbansi)------------- \\
1,5 & 0,58 & 0,44 \\
3 & 0,67 & 0,57 \\
4,5 & 0,68 & 0,59 \\
6 & 0,55 & 0,49 \\
\hline
\end{tabular}

disajikan pada Tabel 3. Hasil analysis of variance (ANOVA) menunjukkan bahwa perlakuan perendaman $\mathrm{HCl}$ dengan konsentrasi yang berbeda tidak berpengaruh nyata $(p>0,05)$ terhadap warna dan kejernihan gelatin tulang kambing

Tinggi rendahnya warna dan kejernihan gelatin tulang kaki kambing ini diduga dipengaruhi $\mathrm{pH}$ yang dihasilkan dari interaksi konsentrasi $\mathrm{HCl}$ yang berbeda. Hal ini sesuai dengan pernyataan Sukkwai et al., (2011) yang mengatakan bahwa perbedaan warna dimungkinkan karena adanya perbedaan kondisi ekstraksi yang di tunjukkan dengan $\mathrm{pH}$ yang rendah pada setiap perlakuan. $\mathrm{pH}$ gelatin tulang kmbing dengan konsentrasi $\mathrm{HCl} 6 \%$ memiliki nilai $\mathrm{pH}$ rendah sehingga nilai warnanya juga semakin terang $(0,55$ absorbansi) namun demikiian nilai warna tidak mempengaruhi sifat fungsional gelatin. Dari grafik diatas dapat terlihat bhwa perlakuan $\mathrm{HCl} 1,5 \%$ memiliki nilai kejernihan yang terendah yaitu (0,44 absorbansi), dan perlakuan perendaman $\mathrm{HCl} 4,5 \%$ memiliki nilai absorbansi tertinggi yaitu $(0,59)$, ini artinya semakin tinggi angka tingkat kejernihan, menunjukkan tinggkat kejernihan gelatin semakin rendah.

Warna pada gelatin dapat dipengaruhi oleh metode pengeringan yang digunakan. Glickman (1969) menambahkan bahwa warna gelatin juga dapat dipengaruhi bahan baku yang digunakan, metode pembuatan dan jumlah ekstraksi. Selain itu juga niali residu mineral dalam gelatin yang semakin tinggi akan mempengaruhi tingkat kecerahan gelatin yang dihasilkan (Harijatmoko, 2004). Secara umum gelatin yang dihasilkan dari tulang kambing ini hampir mendekati standar gelatin
(SNI 1995) yaitu tidak bewarna sampai kuning pucat.

\section{Kadar Protein}

Kadar protein gelatin tulang kambing yang direndam menggunakan $\mathrm{HCl}$ 1,5-6\% selama 24 jam disajikan pada Tabel 4.

Tabel 4. Pengaruh Perendaman $\mathrm{HCl}$ dengan Konsentrasi yang Berbeda Terhadap Kadar Protein Gelatin Tulang Kambing

\begin{tabular}{cc}
\hline Konsentrasi $\mathrm{HCl}(\%)$ & Kadar Protein \\
\hline$-\cdot-------------\cdot \%$-------- \\
\hline 1,5 & $77,51^{\mathrm{a}}$ \\
3 & $77,15^{\mathrm{a}}$ \\
4,5 & $78,09^{\mathrm{a}}$ \\
6 & $73,55^{\mathrm{b}}$ \\
\hline
\end{tabular}

Superskrip yang berbeda menunjukkan perbendaan yang nyata $(\mathrm{p}<0,05)$

Perbedaan kadar protein pada gelatin dapat dipengaruhi oleh baik atau tidaknya kualitas ossein yang dihasilkan pada proses demineralisasi, jenis bahan baku (baik jenis binatangnya maupun jenis bagian tulang yang diekstrak), kesegaran bahan baku yang digunakan juga dapat mempengaruhi kualitas ossein yang dihasilkan sehingga kadar protein gelatin dipengaruhi oleh kesegaran bahan baku. Hal ini sesuai dengan pendapat Ward dan Court (1997) yang menyatakan bahwa kadar protein gelatin bervariasi tergantung pada spesies hewan penghasil, jenis kolagen dan sumber kolagen.

Kadar protein gelatin tulang kambing pada konsentrasi $\mathrm{HCl}$ 1,5-4,5\% mengalami peningkatan seiring dengan penambahan konsentrasi $\mathrm{HCl}$ yang diberrakan yaitu 77,51$78,09 \%$. Diduga peningkatan konsentrasi $\mathrm{HCl}$ menyebabkan semakin banyak ikatan asam amino yang terpecah sehingga semakin banyak protein yang larut pada saat dilakukan proses ekstraksi. Tingginya jumlah protein yang larut menyebabkan kadar protein dalam produk gelatin juga cenderung meningkat, peningkatan konsentrasi larutan akan meningkatkan kolagen yang terlarut (Said et al., 2011). Pemanasan yang berlanjut dalam proses ekstraksi setelah proses curing akan semakin memudahkan kolagen mengalami proses pelarutan atau solubilisasi (Wang et al., 2008). Akan tetapi kadar protein gelatin tulang kambing mengalami penurunan pada 
konsentrasi $\mathrm{HCl} 6 \%$, hal ini mungkin dikarenakan pada konsetrasi $\mathrm{HCl} 6 \%, \mathrm{HCl}$ tidak dapat bekerja dengan baik untuk mengikat mineral kalsium dan jumlah kolagen yang terbebas dapat dikonversi menjadi gelatin.

\section{Kadar Abu}

Semakin tinggi konsentrasi $\mathrm{HCl}$ yang diberikan seiring dengan peningkatan nilai kadar abu yang dihasilkan. Namun demikian kadar abu gelatin tulang kambing yang dihasilkan masih dibawah SNI gelatin yaitu sebesar 3,25\%. Peningakatan nilai kadar abu gelatin tulang kambing pada Ilustrasi 5 .

Tabel 5. Pengaruh perendaman $\mathrm{HCl}$ dengan konsentrasi yang berbeda terhadap Kadar Abu Gelatin Tulang Kaki Kambing

\begin{tabular}{cc}
\hline Konsentrasi $\mathrm{HCl}(\%)$ & Kadar Protein \\
\hline 1,5 & $2,01^{\mathrm{b}}$ \\
3 & $2,33^{\mathrm{b}}$ \\
4,5 & $2,33^{\mathrm{b}}$ \\
6 & $2,86^{\mathrm{a}}$ \\
\hline
\end{tabular}

Superskrip yang berbeda menunjukkan perbendaan yang nyata $(p<0,05)$

Kenaikan kadar abu gelatin tulang kaki kambing berbanding lurus dengan bertambahnya konsentrasi $\mathrm{HCl}$ yang diberikan. Menurut Yuniarfirin (2006) tingginya konsentrasi asam akan menyebabkan semakin banyak garam fosfat yang terikat pada molekul kolagen selama proses asam, sehingga pada saat ektraksi ikut terekstrak bersama kolagen. Selain itu kandungan abu yang dihasilkan pada gelatin berasal dari garam-garam mineral yang terkandung pada tulang yang digunakan.

Tinggi rendahnya kadar abu gelatin ditentukan oleh proses pencucian atau demineralisasi, semakin banyak mineral yang terbuang maka nilai kadar abu semakin rendah, kadar abu yang rendah pada gelatin yang dihasilkan juga diduga karena banyaknya jumlah mineral yang ikut larut dalam proses pencucian dengan air mengalir. Hal lain yang menyebabkan kadar abu yang masih tinggi diduga gelatin yang dihasilkan masih mengandung mineral pada saat pengerigan tidak dilakukan proses pemisahan mineral. Astawan dan Aviana (2003) menambahkan bahwa gelatin yang masih mengandung mineral apabila di abukan tidak akan hilang tetapi akan ikut menjadi abu, sehingga abu gelatin menjadi tinggi. Selain itu kadar abu gelatin sangat dipengaruhi oleh bahan baku yang digunakan serta metode dalam pembuatan gelatin (Ockerman dan Hansen, 2000).

\section{KESIMPULAN}

Berdasarkan hasil penenlitian dapat disimpulkan bahwa, perlakuan perendaman $\mathrm{HCl}$ 1,5-6\% selama 24 jam berpengaruh sangat nyata terhadap kualitas gelatin tulang kaki kambing yaitu kekuatan gel, viskositas, kadar protein dan kadar abu. Direkomendasikan perlakuan perendaman menggunakan $\mathrm{HCl} 3-4,5 \%$ selama 24 jam menghasilkan viskositas, warna dan kejernihan, kekuatan gel, kadar protein dan kadar abu yang terbaik sesuai dengan GMIA (2012) dan SNI (1995).

\section{DAFTAR PUSTAKA}

Astawan, M. dan T. Aviana. 2003. Pengaruh jenis larutan Perendaman Serta Metode Pengeringan Terhadap Sifat Fisik, kimia dan fungsional gelatin dari kulit Ikan Cucut. Jurnal. Teknol. dan Ind. Pangan. 16 (1):7-13.

Astawan, M., P. Hariyad dan A. Mulyani, 2002. Analisis sifat reologi gelatin dari kulit ikan cucut. Journal Teknologi dan Industri Pangan 13 : 38-46

AOAC (Association Of Official Analytical Chemists). 1995. Official Methods Of Analysis Chemist. Vol 1A. AOAC, Inc, Washington.

British Standard 757, 1975. Methods for Sampling and Testing of Gelatin (physichal and chemical method). UK. British standard Institution. Gr 8 . P.BS757, London

Gelatin Manufacturer Institute of America (GMIA). 2012. Gelatin Hand Book. Massachusetts. 
Glicksman, M. 1969. Gum Technology in Food Industry. Academic Press, New York.

Hajrawati. 2006. Sifat Fisik dan Kimia Gelatin Tulang Sapi dengan Perendaman Asam Klorida pada Konsentrasi dan Lama Perendaman yang Berbeda. Institut Pertanian Bogor, Bogor. (Tesis Magister Sains).

Harijatmoko, E. K. 2004. Studi Kualitas Gelatin dari Kulit Sapi Sisa Trimming dengan Dosis kapur Tohor $(\mathrm{CaO})$ dan Lama Perendaman yang berbeda. Skripsi. Fakultas Pertenakan. IPB, Bogor.

Imeson, A. 1992. Thickening and Gelling Agents for Food. Aspen Publishers Inc, New York.

Ockerman, H.W. and C.L. Hansen. 2000. Animal By Product Processing and Utilization. CRC Press, New York.

Poppe J. 1992. Gelatin. Di dalam: Imeson A, editor, Thikening and Gelling Agents for Food. Blackie Academy and Profesional, London.

Saleh, A. R., D. Setiawan, E. Rosihin, R. Wahyudin, S. Rahayu dan Abidin. 2002. Gelatin. Tekno Pangan dan Agroindustri. 1 (9) : 133-135.

Sarabia, A. I., Gomez-Guillen, M. C. and Montero, P. 2000. The effect of added salts on the viscoelastic properties of fish skin gelatin. Journal of Food Chemistry 70: 71-76.

Said, M.I., S. Triatmojo., Y. Erwanto dan A.Fudholi. 2011. Karakteristik gelatin kulit kambing yang diproduksi melalui proses asam basa. J. Agritech. 31(3) : 0216-0455.

Sukkwai, S., K. Kijroongrojana and S. Benjakul. 2011. Extraction of gelatin from bigeye snapper (Priacantuhus tayens) skin for gelatin hydropolysate production. International Food Res. J. 18 (3):1129-1134

Stainsby, G. 1977. The Physical Chemistry Of Gelatin In Solution. In : A. G. Wards and A. Courts. The Science and
Technology of Gelatin. Academic Press, London.

Schrieber, R and H. Gareis. 2007. Gelatin Handbook. Wiley-VCH Verlag $\mathrm{GmbH}$ and Co. KGaA, Weinheim.

Standar Nasional Indonesia. 06. 3735. 1995. Mutu dan Cara Uji Gelatin. Dewan Standarisasi Nasional, Jakarta.

Ward, A. G. dan A. Courts. 1977. The Science and Technology of Gelatin. Academic Press, London.

Wang, L., B.Yang, X. Du, Y. Yang, and J. Liu. 2008. Optimization of conditions for extraction of acid-soluble collagen from grass carp (Ctenopharyngodon idella) by response surface methodology. Innovative Food Sci and Emerging Techn. 9: 604-607.

Yunifirin, H., V.P. Bintoro, A. Suwarastuti. 2006. Pengaruh berbagai konsentrasi asam fosfat pada proses perendaman tulang sapi terhadap rendemen, kadar abu, viskositas gelatin. J. Indonesia Trop. Anim. Agric. 31 (1): 55-61. 